\title{
Antiviral therapy of HCV-cirrhosis: case of sequential treatment and review of literature
}

\author{
Kakharman Yesmembetov ${ }^{\mathbf{1 , 2}}$, Aiymkul
${ }^{1}$ Department of Hepatology, Clinic of Hepatology, \\ Gastroenterology and Transplantation, Astana, Republic \\ of Kazakhstan \\ ${ }^{2}$ Department of Hepatology, Republican Diagnostic \\ Center, University Medical Center, Astana, Republic of \\ Kazakhstan \\ ${ }^{3}$ School of Medicine, Nazarbayev University, Astana, \\ Republic of Kazakhstan
}

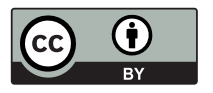

This work is licensed under a

Creative Commons Attribution 4.0

International License

Received: 2018-02-21

Accepted:2018-03-01

UDC: 616.1

\section{J CLIN MED KAZ 2018; 1(47):41-43}

Corresponding author: Kakharman Yesmembetov, Clinic of Hepatology, Gastroenterology and Transplantation, 3, Z05K4F3, Kerei and Zhanibek Khans Street, Astana, Republic of Kazakhstan Tel.: +77017632092

E-mail: kyesmembetov@gmail.com
Abstract

This clinical case demonstrates a history of 40-year old male with decompensated liver cirrhosis due to hepatitis $\mathrm{C}$ (genotype 1). The patient was started on direct acting antiviral therapy with sofosbuvir and simeprevir in order to decrease rate of disease progression. Treatment was associated with marked improvement of patient's condition and resolving of ascites. Negative viremia was achieved after week 8 of antiviral therapy and the treatment was completed on week 12. However, evaluation on post-treatment week 12 has demonstrated recurrence of hepatitis $\mathrm{C}$ virus with sharp increase of liver transaminases of higher than 20 times upper limit normal. Second round of direct acting antiviral agents including ombitasvir, paritaprevir, dasabuvir and ritonavir was started. Negative viremia was achieved on week 4 with consequent demonstration of end of treatment and sustained virological response at 12 weeks post-treatment. This clinical case demonstrates need for personalized approach to antiviral therapy in each patient with modification of the treatment regimen by prolongation or implementing additional antiviral agent, if needed.

Key words: liver cirrhosis, hepatitis $C$, liver transplantation, liver cirrhosis treatment, hepatitis $\mathrm{C}$ treatment

\section{ГЕПАТИТ С ВИРУСЫНАН ТУЫНДАҒАН БАУЫР ЦИРРОЗЫ: ТІЗБЕКТІ ЕМДЕУ ЖАҒДАЙЫ ЖӘНЕ МАҚАЛАЛАРДЫ ШОЛУ}

Есмембетов Қ.І. ${ }^{1,2}$, Әшімханова А.А. ${ }^{3}$, Қалиасқарова К.С.,2

${ }^{1}$ Гепатология бөлімшесі, Гепатология, гастроэнтерология және тағамтану клиникасы, Астана, Қазақстан Республикасы

${ }^{2}$ Гепатология бөлімшесі, Респубикалық диагностикалық орталық, University Medical Center, Астана, Қазақстан Республикасы

${ }^{3}$ Медицина мектебі, Назарбаев Университет, Астана, Қазақстан Республикасы

\section{ТҰЖЫРЫМДАМА}

Мақалада 40 жастағы созылмалы гепатит C (генотип 1b) салдарынан дамыған асқынған бауыр циррозына шалдыққан науқастың клиникалық жағдайы баяндалады. Бауыр циррозының асқынуын алдын-алу мақсатында науқасқа софосбувир және симепревирмен қатар вирусқа қарсы ем тағайындалады. Ем барысында науқас жағдайының едәуір жақсаруы және асциттің қайтуы байқалады. Емнің 8-ші аптасынан өте вирус қаннан жойылып, ем 12-ші аптада аяқталады. Ем аяқталғаннан кейін 12 апта өткен соң жасалған жоспарлы тексеру гепатит С вирусының қайта оралғанын және бауыр трансаминазалары деңгейінің шектен тыс 20 есе астам жоғарылағанын анықтайды. Өткен емді есепке ала отырып, вирусқа тікелей әсер ететін омбитасвир, паритапревир, дасабувир және ритонавир дәрмектерін қатар қолдана отырып ем тағайындалады. Емнің 4-ші аптасында вирус қаннан алғаш жойылып, ем аяқталғанда және 12 аптадан кейін оның қайта оралмағаны көрсетілді. Бұл клиникалық жағдай вирусқа қарсы емнің әр науқасқа қатысты жеке қарастырылу қажеттілігін және керегінше емнің өзгертілу керектігін көрсетеді.

Кілт сөздер: бауыр циррозы, гепатит С, бауыр трансплантациясы, бауыр циррозы емі, гепатит С емі

\section{ПРОТИВОВИРУСНАЯ ТЕРАПИЯ НСУ-ЦИРРОЗА: СЛУЧАЙ ПОСЛЕДОВАТЕЛЬНОГО ЛЕЧЕНИЯ И ОБЗОР ЛИТЕРАТУРЫ}

Есмембетов К.И. ${ }^{1,2}$, Ашимханова А.А. ${ }^{3}$, Калиаскарова К.С.,

${ }^{1}$ Отделение гепатологии, Клиника гепатологии, гастроэнтерологии и питания, Астана, Республика Казахстан

${ }^{2}$ Отделение гепатологии, Республиканский диагностический центр, University Medical Center, Астана, Республика Казахстан

${ }^{3}$ Школа медицины, Назарбаев Университет, Астана, Республика Казахстан 


\section{PEЗЮME}

В статье представлен клинический случай 40-летнего мужчины с декомпенсированным циррозом печени в исходе хронического гепатита C (генотип $1 \mathrm{~b})$. В целях снижения темпов прогрессирования заболевания была начата комбинированная противовирусная терапия софосбувиром и симепревиром. Лечение сопровождалось значительным улучшением состояния пациента и купированием асцита. Авиремия вируса гепатита С была достигнута после 8-й недели противовирусной терапии, противовирусная терапия была завершена на 12-й неделе. Плановое обследование на 12-й неделе после завершения противовирусной терапии продемонстрировало рецидив вируса гепатита C с резким повышением трансаминаз печени более чем в 20 раз выше нормы. С учетом предыдущего опыта противовирусной терапии, было начато лечение комбинацией

\section{Введение}

Гепатит С является одним из ведущих причин развития цирроза печени в мире. Противовирусная терапия HCV-инфекции позволяет предотвратить развитие цирроза печени, при наличии последней, замедлить ее прогрессирование, и таким образом уменьшить риск осложнений и печеночносвязанной смертности. Актуальность противовирусной терапии у пациентов в листе ожидания трансплантациипечениобоснованавозможностьюуменьшения темпов прогрессирования заболевания и необходимостью профилактики реинфекции вирусом гепатита С после трансплантации печени. Количество зарегистрированных с 2013 года препаратов прямого противовирусного действия для лечения гепатита $\mathrm{C}$ неуклонно растет, что позволяет подобрать оптимальную комбинацию препаратов для лечения $\mathrm{HCV}$-инфекции с учетом генотипа вируса, стадии печеночного процесса и профиля сопутствующих заболеваний.

\section{Клинический случай}

Мужчина, 40 лет, был включен в лист ожидания трансплантации печени в связи с декомпенсированным циррозом печени в исходе хронического гепатита С. Из анамнеза известно, что заболевание манифестировало в 2011 году с отеков нижних конечностей с последующим их спонтанным разрешением. В начале 2014 года было впервые отмечено развитие асцита, в апреле 2014 года у пациента был диагностирован цирроз печени в исходе хронического гепатита С. В связи с отсутствием регистрации противовирусных препаратов прямого действия на тот момент в Казахстане, пациент был рассмотрен в качестве кандидата на лечение комбинацией пегилированного интерферона альфа2 и рибавирина, с учетом высокой виремии (9.980.000 копий/мл) и генотипа $1 \mathrm{~b} \mathrm{HCV}$. Однако, стадия декомпенсации цирроза печени (10 баллов по шкале Child-Pugh, индекс Model for EndStage Liver Disease - 13) с клинически выраженной портальной гипертензией (асцит, варикозное расширение вен пищевода 2 степени), анемия и цитопения являлись противопоказаниями к двойной терапии. Учитывая вышеизложенное, пациенту была рекомендована противовирусная терапия софосбувиром (400 мг в сутки) и симепревиром (150 мг в сутки) в течение не менее 12 недель, исходя из доступных рекомендаций и данных клинических исследований по состоянию на начало 2014 года [1-4].

В связи с отсутствием регистрации данных препаратов в Казахстане, пациент начал противовирусную терапию в США в июне 2014 года после предварительного эндоскопического лигирования варикозно-расширенных вен пищевода. На фоне противовирусной терапии была достигнута следующая препаратов прямого действия омбитасвир, паритапревир, дасабувир и ритонавир. Негативная виремия вируса гепатита C была достигнута на 4-й неделе лечения с последующей демонстрацией непосредственного и устойчивого вирусологического ответа через 12 недель после завершения терапии. Данный клинический случай демонстрирует необходимость персонализированного подхода к противовирусной терапии сподбором оптимального режима лечения, и при необходимости, модификации схемы путем пролонгации или применения дополнительных противовирусных препаратов.

Ключевые слова: цирроз печени, гепатит С, трансплантация печени, лечение цирроза печени, лечение гепатита C

Примечание: в целях выполнения этой работы не были использованы какие-либо гранты или целевое финансирование.

динамика виремии: исходная вирусная нагрузка 3.220 .400 копий/мл, неделя 4 - 549 копий/мл, неделя 8 - 39 копий/ мл, неделя 12 - отсутствие РНК HCV. Авиремия HCV сопровождалась нормализацией уровня билирубина и аланинаминотрансферазы(АЛТ), уменьшением выраженности портальной гипертензии с разрешением асцита и значительным улучшением самочувствия пациента. Улучшение состояния пациента отразилось на снижении прогностических индексов цирроза печени (7 баллов по шкале Child-Pugh, индекс Model for End-Stage Liver Disease - 8) с дальнейшей приостановкой продвижения больного в листе ожидания пересадки печени.

В связи с достижением авиремии HCV лишь после 8-й недели противовирусной терапии софосбувиром и симепревиром, пациенту была рекомендована пролонгация лечения, однако лечение было завершено на 12-й неделе. Плановое обследование через 12 недель после завершения противовирусной терапии продемонстрировало рецидив $\mathrm{HCV}$ с уровнем виремии 320967 копий/мл, резким 21- и 24-х кратным повышением аланинаминотрансферазы и аспартатаминотрансферазы выше нормы, соответственно. Рецидив HCV также сопровождался повторным развитием асцита. С учетом опыта предыдущего лечения, в январе 2015 года была инициирована повторная попытка противовирусной терапии комбинацией омбитасвира (12.5 мг), паритапревира (75 мг), дасабувира (250 мг) и ритонавира (50 мг) [5]. Второй курс противовирусной терапии позволил добиться авиремии $\mathrm{HCV}$ на 4-й неделе лечения с последующей нормализацией сывороточных показателей функции печени. Сывороточный клиренс HCV был подтвержден на 24-й неделе лечения и через 12 недель после завершения противовирусной терапии. Однако, несмотря на достижение устойчивого вирусологического ответа, в октябре 2015 года состояние пациента начало прогрессивно ухудшаться, в связи с чем он был восстановлен в листе ожидания пересадки печени.

\section{Обсуждение}

ЛПротивовирусная терапия гепатита С на стадии цирроза печени в эру лечения препаратами интерферона представляла непростую задачу, обладая ограниченной эффективностью, высокой частотой нежелательных явлений, приводивших к снижению доз препаратов и/или отмене лечения, а также сопровождаясь риском усугубления печеночной недостаточности и портальной гипертензии и развития печеночносвязанной смерти [6]. С началом применения противовирусных препаратов прямого действия с 2013 года значительно повысилась частота устойчивого вирусологического ответа (УВО), позволяя добиться у пациентов с компенсированным циррозом печени показателей, идентичных с результатами у больных без цирроза печени, в 
то же время при гораздо менее выраженных нежелательных явлениях у пациентов.

По состоянию на весну 2014 года, комбинация софосбувира и симепревира являлась единственным доступным полностью пероральным противовирусным режимом терапии для пациентов с генотипом 1 HCV. Однако, данные клинических исследований рекомендовали применение симепревира с осторожностью у пациентов с классом В и С цирроза печени по шкале Child-Pugh в связи с риском избыточного накопления в крови и гипербилирубинемии. Тем не менее, несмотря на недостаток данных по применению симепревира у пациентов с декомпенсированным циррозом печени, полностью пероральная противовирусная терапия, желательно без рибавирина, была рекомендована EASL (Европейской ассоциацией по изучению печени) для больных в листе ожидания трансплантации печени [7]. Данная рекомендация была основана на результатах исследования фазы IIb COSMOS [8]. В рамках данного исследования во второй когорте 87 ранее не леченных и не ответивших на предыдущее лечение пациентов со стадией фиброза F3-4 по METAVIR оценивался эффект лечения в течение 12 и 24 недель, как с рибавирином, так и без него. Частота УВО была $100 \%$ у ранее не леченных пациентов с рибавирином (7/7) и без него (12/12). У пациентов, не ответивших на предыдущее лечение, частота УВО составила 100\% в подгруппе с применением рибавирина $(7 / 7)$ и 93\% (14/15) без рибавирина. Важным дополнением является то, что в исследовании не было зарегистрировано случаев вирусологического прорыва.

В нашем клиническом случае авиремия HCV у пациента была достигнута лишь после 8-й недели противовирусной терапии софосбувиром и симепревиром, что требовало пролонгации лечения свыше стандартной длительности в 12 недель. Однако, терапия была прервана на 12-й неделе, что сопровождалось рецидивом $\mathrm{HCV}$ через 12 недель после завершения лечения.

При планировании повторной попытки противовирусной терапии по состоянию на конец 2014 года в качестве альтернативных режимов выбора противовирусной терапии без рибавирина для субкомпенсированного цирроза печени в исходе $1 \mathrm{~b}$ генотипа $\mathrm{HCV}$-инфекции, были рассмотрены комбинации софосбувир/ледипасвир и софосбувир/ даклатасвир, продемонстрировавшие отличные результать лечения у необходимой группы пациентов [9, 10]. Однако, с учетом предыдущего опыта лечения у данного пациента, в первую очередь рассматривались режимы терапии без софосбувира и симепревира. Единственным режимом выбора, отвечавшим всем вышеперечисленным требованиям была комбинация омбитасвира (12.5 мг), паритапревира (75 мг), дасабувира (250 мг) и ритонавира (50 мг) [11]. На фоне данного лечения, авиремия HCV была отмечена на 4-й неделе с дальнейшим достижением непосредственного и устойчивого вирусологического ответа. Однако, через 4 месяца после констатации УВО, пациент был вновь восстановлен в листе ожидания трансплантации печени в связи с прогрессированием заболевания.

\section{Выводы}

Данный клинический случай демонстрирует необходмость персонализированного подхода к противовирусной терапии с подбором оптимального режима лечения, и при необходимости, модификации схемы путем пролонгации или применения дополнительных противовирусных препаратов. Противовирусная терапия позволила отложить постановку в лист ожидания пересадки печени на 16 месяцев, что важно с учетом нехватки донорских органов и риска реинфекции трансплантата HCV.

Disclosures: There is no conflict of interest for all authors..

\section{Литература}

1. Iacobellis A, Siciliano M, Perri F, et al. Peginterferon alfa-2b and ribavirin in patients with hepatitis $\mathrm{C}$ virus and decompensated cirrhosis: A controlled study. J Hepatol. 2007; 46(2):206-212.

2. Carrión JA, Martínez-Bauer E, Crespo G, et al. Antiviral therapy increases the risk of bacterial infections in HCV-infected cirrhotic patients awaiting liver transplantation: A retrospective study. J Hepatol. 2009; 50(4):719-728.

3. Vezali E, Aghemo A, Colombo M. A review of the treatment of chronic hepatitis C virus infection in cirrhosis. Clin Ther. 2010; 32(13):2117-2138.

4. Hagan LM, Sulkowski MS, Schinazi RF. Cost analysis of sofosbuvir/ribavirin versus sofosbuvir/simeprevir for genotype 1 hepatitis $C$ virus in interferon-ineligible/intolerant individuals. Hepatology. 2014; 60(1):37-45.

5. Gamal N, Vitale G, Andreone P. ABT-450: a novel agent for the treatment of CHC genotype 1: focus on treatment-experienced patients. Expert Rev Anti Infect Ther. 2015; 13(3):295-304.

6. Vezali E, Aghemo A, Colombo M. A review of the treatment of chronic hepatitis C virus infection in cirrhosis. Clin Ther. 2010; 32(13): 2117-2138.

7. Pawlotsky J.M, Aghemo A, Dusheiko G, Forns X, Puoti M, Sarrazin C. EASL recommendations on treatment of hepatitis C. 2014. http://files.easl.eu/easl-recommendations-on-treatment-of-hepatitis-C/mobile/index.html\#p=1.

8. Jacobson I, Ghalib RH, Rodriguez-Torres M, Younossi ZM, Corregidor A, Sulkowski M. et al. SVR results of once-daily regimen of simeprevir (TMC435) and sofosbuvir (GS-7977) with or without ribavirin in cirrhotic and non-cirrhotic HCV genotype 1 treatment-naïve and prior null-responder patients: the COSMOS study. Hepatology. 2013; 58(1):1379A.

9. Sulkowski MS, Gardiner DF, Rodriguez-Torres M, Reddy KR, Hassanein T, Jacobson I. et al. Daclatasvir plus sofosbuvir for previously treated or untreated chronic HCV infection. $N$ Engl J Med. 2014; 370(3):211-221.

10. Bourliere M, Bronowski JP, de Ledinghen V, Hezode C, Zoulim F, Mathurin P. et al. Ledipasvir/sofosbuvir fixed dose combination is safe and efficacious in cirrhotic patients who have previously failed protease-inhibitor based triple therapy. Hepatology. 2014; 60:1271A.

11. Poordad F, Hezode C, Trinh R, Kowdley KV, Zeuzem S, Agarwal K. et al. ABT-450/r-ombitasvir and dasabuvir with ribavirin for hepatitis C with cirrhosis. N Engl J Med. 2014; 370(21):1973-1982.

How to cite this article: Kakharman Yesmembetov, Aiymkul Ashimkhanova, Kulpash Kaliaskarova. Antiviral therapy of HCVcirrhosis: case of sequential treatment and review of literature [in Russian]. J Clin Med Kaz. 2018; 1(47):41-43 